\title{
Notes
}

\section{The Linear Garden: A Unique, Inexpensive, and Effective Way to Facilitate Plant Identification and Roadside Beautification}

\author{
Sandra B. Wilson ${ }^{1,2,3}$, Keona L. Muller ${ }^{1}$, Judith A. Gersony ${ }^{1}$, \\ and Brian T. Scully ${ }^{1,2}$
}

ADDITIONAL INDEX WORDs. ornamentals, distance education, public gardens, web-based plant images, plant collections, landscape design

$\mathrm{T}$ There are over 2500 registered botanical gardens worldwide that receive 200 million visitors every year (Botanic Gardens Conservation International, 2007). Aside from appealing to our aesthetic sense, botanic gardens and arboreta can be used as outdoor teaching laboratories. Numerous plant collections affiliated with universities have been integrated into landscape design, landscape construction, herbaceous and woody plant identification, and turfgrass management curricula (Hamilton, 1999; Olsen et al., 1999; VanDerZanden and Cook, 1999; Wilson et al., 2004). With the advancements in web technology, these learning exercises can reach much broader audiences. For example, Wilson and Danielson (2005)

We gratefully acknowledge Andreas Daehnick, Randy Burton, and Patricia Frey for their preparation and installation assistance, and Florida's Nursery and Landscape Industry for donating the plant material. This is Indian River Research and Education Center Journal Series No. IRREC R-080701.

${ }^{1}$ Department of Environmental Horticulture, Indian River Research and Education Center, University of Florida IFAS, Fort Pierce, FL 34945

${ }^{2}$ Associate Professor. Current address: Crop Protection and Management Research Unit, USDA-ARS, P.O. Box 748, Tifton, GA 31794.

${ }^{3}$ Corresponding author. E-mail: sbwilson@ifas.ufl.edu. created an interactive virtual plant identification and use instrument for a native landscaping course, where students can walk virtually through a botanical garden and self-select plants for additional taxonomic detail.

Long-term maintenance costs and availability of space are two common issues encountered at university gardens. The concept of a linear garden originated when existing university gardens were at maximum plant capacity. The need to teach students a large diversity of plant material in a limited amount of time and space paralleled local interest in roadside beautification. With minimal installation and maintenance costs, a linear garden was established along the length of the road perpendicular to entrances to adjacent University of Florida and U.S. Department of Agriculture facilities.

A single grass strip ( $3 \mathrm{ft}$ wide $\times$ $2426 \mathrm{ft}$ long) was treated with herbicide and rotary-tilled with a tractor. A vegetable bed press was used to form 8 -inch-tall beds, upon which a plastic mulch machine was used to apply the single row of semipermeable landscape fabric. To irrigate the entire length of the bed with similar pressure, a 1.25-inch submain plastic tubing line was installed and connected every $100 \mathrm{ft}$ with 1 -inch risers and 25-psi pressure regulators. Drip emitters were used to deliver water at $2 \mathrm{gal} / \mathrm{h}$.

Eight hundred seventeen plants (comprising 237 different taxa) were planted with spacing adjusted to accommodate their mature plant width. The garden was designed to showcase specimen plants and display other common landscape plants used in the south-central Florida region with attention to foliage type and texture, flower color, plant size and form, and seasonality (Fig. 1). Year-round viewing interest was obtained by using different plant types, including 62 species of trees, 23 palms, 127 shrubs, 18 groundcovers, four vines, and three grasses.

Despite the linear restriction of the garden, plant arrangement was based on five design principles, including color, line, form, texture, and scale. To achieve this, a master spreadsheet was developed to categorize leaf persistence, mature width and height, flowering time, and flower and foliage color. A computer-aided drafting program (AutoCad 2002, version 3.3; Autodesk, San Rafael, CA) was used to create the base sheet, schematic, and master plans. Rhythm, unity, and structure were achieved through alternation of large and small trees with deciduous and evergreen leaf persistence. A vertical transition was created by grouping and replicating trees, vine structures, and palms. Plants of similar color, form, and texture were placed equidistant from the center of each tree grouping, creating not only repetition but balance through symmetry. Shrubs, groundcovers, and grasses were placed between all trees and palms to create color, scale, and texture.

\begin{tabular}{llll}
\hline $\begin{array}{l}\text { Units } \\
\begin{array}{l}\text { To convert U.S. to SI, } \\
\text { multiply by }\end{array}\end{array}$ & U.S. unit & SI unit & $\begin{array}{l}\text { To convert SI to U.S., } \\
\text { multiply by }\end{array}$ \\
\hline 0.3048 & $\mathrm{ft}$ & $\mathrm{m}$ & 3.2808 \\
3.7854 & $\mathrm{gal}$ & $\mathrm{L}$ & 0.2642 \\
2.54 & inch(es) & $\mathrm{cm}$ & 0.3937 \\
6.8948 & $\mathrm{psi}$ & $\mathrm{kPa}$ & 0.1450
\end{tabular}



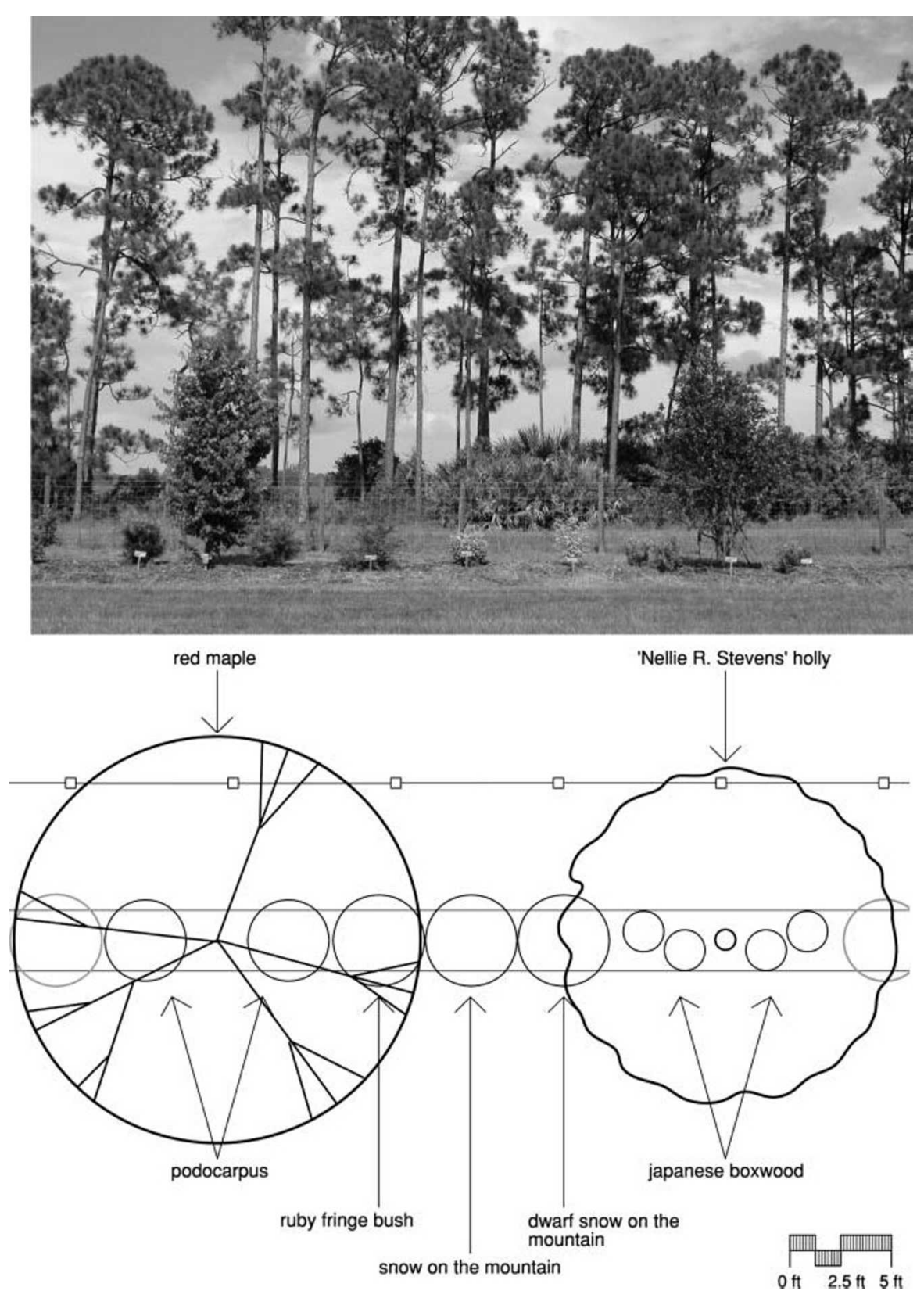

Fig. 1. Representative 43-ft section of the 2426- $\mathrm{ft}$ linear garden located parallel to South Rock Road and the University of Florida Indian River Research and Education Center, Fort Pierce. Elevation view (top) corresponds to plan view (bottom), consisting of red maple (Acer rubrum), podocarpus (Podocarpus macrophyllus), ruby fringe bush (Loropetalum chinense var. rubrum), snow on the mountain (Breynia disticha), dwarf snow on the mountain (Breynia disticha 'Nana'), japanese boxwood (Buxus microphylla var. japonica), and 'Nellie R. Stevens' holly (Ilex aquifolium $\times$ cornuta). Note: $1 \mathrm{ft}=0.3048 \mathrm{~m}$.

Once planted, trees were staked as needed and the entire linear bed was mulched. Plants were fertilized according to size with $15 \mathrm{~N}-$ $3.9 \mathrm{P}-10 \mathrm{~K}$ controlled-release fertilizer (Osmocote Plus 15-9-12; The Scotts Co., Marysville, $\mathrm{OH}$ ) and were drip-irrigated for 60 min every other day or as needed based on climatic and seasonal conditions. Each species was labeled with ultraviolet stable structure, and form. The linear garden is presently used by students in five courses, visited by numerous community colleges, garden clubs, and extension offices, and viewed daily by everyone who drives by. The linear architecture of the garden is useful for panoramic plant comparisons and eliminates design confusion often encountered with more typical, smallscale contiguous gardens that require a similar magnitude of plant diversity. In addition to containing about 3.7 times more plants per unit area than a traditional teaching garden, the linear configuration also enables larger scale industrial mowers to be used around the beds, thus minimizing detailed labor.

In summary, a linear garden offers a time-efficient way to learn plant material, requires less space and maintenance compared with traditional gardens, beautifies the roadside with interest all year, and uniquely contrasts plant form, color, and texture concepts. For educational purposes, original plant information data sheets, plant images, computer-aided design drawings, and plant nomenclature may be downloaded directly from the linear garden website (Muller, 2007).

\section{Literature cited}

Botanic Gardens Conservation International. 2007. Education in botanic gardens. 18 May 2007. <http://www.bgci. org/education/home $>$.

Hamilton, S.L. 1999. The roles of the University of Tennessee gardens in a public horticulture teaching program. HortTechnology 9:552-556.

Muller, K.L. 2007. Linear garden. 7 June 2007. <http://irrecenvhort.ifas.ufl.edu/ LinearGarden/index.htm>.

Olsen, S., D. Amundsen, B. Varga, D. Minch, and D. Anderson. 1999. The Utah Botanical Gardens: An educational resource for the university and the community. HortTechnology 9:562-565.

Van Der Zanden, A. and T. Cook. 1999. A multifunctional horticulture teaching garden at Oregon State University. HortTechnology 9:549-551.

Wilson, S.B. and H.E. Danielson. 2005. Interactive virtual plant identification and use. Hort Technology 15:729-730.

Wilson, S.B., L.A. Krumfolz, and J.A. Gersony. 2004. Design, development and use of an ornamental teaching garden at the Indian River Research and Education Center, University of Florida. Acta Hort. 641:137-143. 